\title{
Histamine Measurement
}

National Cancer Institute

\section{Source}

National Cancer Institute. Histamine Measurement. NCI Thesaurus. Code C80189.

The determination of the amount of histamine present in a sample. 